\title{
Intravitreal injection of polysorbate 80: a functional and morphological study
}

\section{Injeção intravítrea de polissorbato 80: estudo funcional e morfológico}

Francisco Max Damico ${ }^{1}$; Fábio Gasparin ${ }^{1}$; Gabriela lourençon loshimoto ${ }^{2}$; Thais Zamudio Igami ${ }^{1}$; Armando da Silva Cunha Jr. ${ }^{3}$; Silvia ligorio Fialho4; Andre Mauricio Liber²; lucy Hwa-Yue Young ${ }^{5}$; Dora Fix Ventura ${ }^{2}$.

\section{A B S T R A C T}

\begin{abstract}
Objective: to determine the functional and morphological effects at rabbits retina of PS80 concentration used in the preparation of intravitreal drugs. Methods: eleven New Zealand rabbits received a intravitreal injection of $0.1 \mathrm{ml}$ of PS80. As control, the contralateral eye of each rabbit received the same volume of saline. Electroretinography was performed according to a modified protocol, as well as biomicroscopy and retina mapping before injection and seven and ten days after. Animals were euthanized in the 30th day and the retinas were analyzed by light microscopy. Results: eyes injected with PS80 did not present clinical signs of intraocular inflammation. Electroretinography did not show any alteration of extent and implicit time of $a$ and $b$ waves at scotopic and photopic conditions. There were no morphological alterations of retinas at light microscopy. Conclusion: intravitreal injection of PS80 in the used concentration for intravitreal drug preparations do not cause any functional or morphological alterations of rabbit retinas. These results suggest that PS80 is not toxic to rabbit retinas and may be safely used in the preparation of new lipophilic drugs for intravitreal injection.
\end{abstract}

Keywords: Polysorbates. Retina. Electroretinography. Intravitreal Injections. Morphological and Microscopic Findings.

\section{INTRODUCTION}

$\mathrm{D}$ rug access to the retina and choroid has always been a challenge to ophthalmologists due to the existence of two anatomic barriers (internal and external blood-retinal barriers) that impairs penetration of drugs in the posterior segment of ocular bulbus. Treatment of blindness secondary to most prevalent retina and choroid diseases (macular degeneration related to age and diabetic retinopathy) has changed dramatically with the use of intravitreal injection of therapeutic agents in the posterior segment of ocular bulbus ${ }^{1}$. Intravitreal injection of drugs overcomes external blood-retinal barrier and assures that retina and choroid receive therapeutic level of drugs, lowering significantly systemic absorption and consequent toxicity. According to Brazilian and World legislation, intravitreal injection of drugs is a surgical procedure and must be performed under rigorous aseptic technique.
Most commonly injected drugs in the vitreous are monoclonal antibodies (particularly inhibitors of the vascular endothelium growth factor), corticosteroids and antibiotics, but, in theory, any drug can be injected in the vitreous. However, some pharmacological aspects must be considered, such as the aqueous solubility, pharmacokinetics and biochemical proprieties of the compounds, as well as their interaction with the vitreous ${ }^{2}$.

Polysorbates, a class of non-ionic surfactants, are very useful excipients in several pharmaceutic formulations for intravenous use with different objectives. Polysorbates increase drug solubility in suspensions with low or no-solubility, to obtain aqueous dispersions. In those cases, surfactant concentration varies from $0.05 \%$ to $0.5 \%$, depending on the solid content of formulation. Polysorbates also are used in the formula of injectable solutions to increase absorption of soluble drugs due to micelle formation. Also, polysorbates are useful to sta-

1 - USP Medical School, Department of Ophthalmology and Otolaryngology, São Paulo, SP, Brazil. 2 - USP Institute of Psychology, Department of Experimental Psychology, São Paulo, SP, Brazil. 3 - UFMG School of Pharmacy, Department of Pharmaceutic Products, Belo Horizonte, MG, Brazil. 4 - Fundação Ezequiel Dias, Technologic Pharmaceutic Development Division, Belo Horizonte, MG, Brazil. 5 - Harvard Medical School, Department of Ophthalmology, Boston, MA, USA. 
bilize proteins in formulas with monoclonal antibodies. Virtually, all formulas contain polysorbate 20 or 80 .

Polysorbate 80 , also known as polyoxietilensorbitan-20 mono-oleate or Tween $80 \AA$ (MW: 428.60, FM: C24H44O6, aqueous solubility: $5-10 \mathrm{~g} / 100 \mathrm{ml}$ at $23^{\circ} \mathrm{C}$ ) is a polysorbate used to stabilize aqueous formulations of drugs used topically, intravenously and intravitreal. It is also a solubilizer used in eye drops and an important component of lipophilic suspended drugs.

Safety of systemic use of PS80 is controversial. PS80 has no neurotoxicity in newborn rats following administration of high oral doses during pregnancy, and do not cause development disturbances, functional alterations of central nervous system, and alterations of locomotion or of reflexes ${ }^{3}$. In adult animals, oral intake of high doses of PS80 is safe in mice, rats, dogs and apes ${ }^{4}$. However, intraperitoneal injection of PS80 in newborn female rats cause morphological and functional alterations of uterus and ovaries ${ }^{5}$. Also, PS80 may be associated to non-immune anaphylactic reaction, following intravenous administration during pregnancy ${ }^{6}$.

PS80 effects on the eye surface were studied in several experimental models. Sub-tenon injection of PS80 in rabbits caused less toxicity in eye surface than other commonly used excipients commonly used in topic formulations for ocular use, such as carboxymethylcellulose, polyethylene glycol, benzylic alcohol, benzalkonium chloride and methylcellulose ${ }^{7}$. PS80 also seems to have a protective mechanism in the corneal epithelium of cells maintained in culture, reducing the toxicity induced by benzalkonium chloride, a commonly used excipient used in eye drops ${ }^{8,9}$.

Formula most used commercially of triamcinolone acetonide (TA) contains PS80. TA is a synthetic glucocorticoid with long-lasting effect that has been widely used in the treatment of retinal diseases by intravitreal injection, but safety studies show controversial results. Some in vivo experimental studies suggest that TA intravitreal injection, which formula contains PS80, is safe ${ }^{10-}$ 12. However, other experimental studies suggest that TA formulation without preservative is less toxic to retina after intravitreal injection than most common formulas ${ }^{13-15}$. Since TA vehicle formulation has many compounds, such as benzylic alcohol, carboxy-methylcellulose, PS80, sodium hydroxide and hydrochloric acid, the role of each compound in retinal toxicity is still uncertain ${ }^{16-18}$.

Although PS80 is frequently used in the preparation of formulations for ocular use, including drugs for intravitreal use, its effect on retina after intravitreal injection has never been studied. The objective of the present study is to determine functional and morphological alterations of rabbit retina caused by PS80, at the same concentration used for the preparation of new drugs for intravitreal use.

\section{METHODS}

Eleven New Zealand non-pigmented rabbits (weighting from 2 to $3 \mathrm{~kg}$ ) were used. Animals were treated according to the recommendations of the Association for Research in Vision and Ophthalmology Statement for the Use of Animals in Ophthalmic and Vision Research. Experiments were approved by the Ethic Commission of Animal Experimentation of Biomedical Science Institute of the University of São Paulo \#029, sheet 43, book 2, and by the Ethic Commission of Research in Animals of the Psychological Institute of University of São Paulo (\#07.2010).

Animals were kept in individual cages in a cleardark cycle of 12 hours, and free access to water and food. Pupils were dilated with tropicamide $0.5 \%$ eye drops and eyes were anesthetized with proxymetacaine eye drops. Before intravitreal injection, electroretinography and euthanasia, animals were anesthetized with intramuscular injection of ketamine hydrochloride $(35 \mathrm{mg} /$ $\mathrm{kg}$ ) and xylazine hydrochloride $(5 \mathrm{mg} / \mathrm{kg})$. Animals were sacrificed by intravenous injection of sodium pentobarbital (40mg/kg).

\section{Intravitreal Injection}

Right before intravitreal injection, it was performed paracentesis of anterior camera (30G needle), removing $0.1 \mathrm{ml}$ of aqueous humor to avoid significant increase of ocular pressure. Under direct visualization, right eye of each animal were submitted to an intravitreal injection of $0.1 \mathrm{ml}$ of PS80 (0.4\% w/v, pH 6.6-6.8, osmolarity $288-318 \mathrm{mOsm} / \mathrm{kg} \mathrm{H}_{2} \mathrm{O}$ ) using a $30 \mathrm{G}$ needle attached to a tuberculin syringe. Intravitreal injection was performed approximately at $3 \mathrm{~mm}$ posterior to lim- 
bo. Left eye received an intravitreal injection of sterile saline and used as control.

\section{Ophthalmologic Exam}

Animals were submitted to biomicroscopy and indirect binocular ophthalmoscopy before and right after intravitreal injections, repeated in the 7 th and 14 th days after injections.

\section{Electroretinography}

Both eyes were submitted to full-field electroretinography (ERG) before and after seven and 14 days of injection. For ERG, contact lens were applied attached to bipolar corneal electrodes in both eyes and a ground electrode was fixed at the animal ear. Animals were positioned in a Faraday cage $(60 \times 60 \mathrm{~cm})$ and the luminous stimulation was generated by a Ganzfeld stimulator controlled by a computer system. ERG signs were amplified and digitalized. Data were analyzed by LabVIEW® computer software. Luminous stimuli band was calibrated to vary from 0.3 to $1000 \mathrm{~Hz}$.

The protocol used for ERG acquisition was the one suggested by the International Society for Clinical Electrophysiology of Vision (ISCEV) ${ }^{19}$ modified for acquirement of some additional information in experimental studies. For obtaining scotopic answers, animals were adapted in the dark for 30 minutes and were submitted to stimuli with five different luminous intensity $(0.001$, $0.01,0.1,1$ and $10 \mathrm{~cd} . \mathrm{s} / \mathrm{m}^{2}$ ). After adaptation for ten minutes to light, they were submitted to luminous stimuli with $1 \mathrm{~cd} . \mathrm{s} / \mathrm{m}^{2}$ with background illumination of $25 \mathrm{~cd} / \mathrm{m}^{2}$.

$A$ and $b$ waves were recorded and their amplitude and implicit time were analyzed. A wave amplitude was measured from baseline to minimum amplitude registered after presentation of stimuli. Implicit time was measured from the beginning of luminous stimulus until the a wave peak. B wave amplitude was measured from $a$ wave peak to $b$ wave peak, and the implicit time of $b$ wave corresponded to the necessary time for that peak.

ERG dynamic interval at scotopic condition was evaluated by a graphic of median amplitude versus luminous stimulus intensity. Curves were obtained by the equation of Naka-Rushton: $V=V \max . \ln / \mathrm{Kn}+\mathrm{In}$; Vmax is the saturation amplitude of $b$ wave, $I$ is the intensity of luminous stimulus, $\mathrm{K}$ is necessary luminous intensity for obtaining $50 \%$ of $\mathrm{Vmax}$ and $\mathrm{n}$ is the curve inclination, representing the dynamic interval of the measured wave.

\section{Morphological Analysis}

Animals were sacrificed 30 days after intravitreal injections and their eyes were processed for light microscopy, after euthanasia, posterior eye segments were fixed in ALFAC solution. After inclusion in paraffin, they were submitted to $7 \mu \mathrm{m}$ slices that were dyed with hematoxylin and eosin and analyzed under light microscopy. Thickness and retinal organization were analyzed at retinal inferior medium periphery of all eyes.

\section{Statistical Analysis}

Amplitude and implicit times were described as medium \pm standard deviation. Results were analyzed by ANOVA variance analysis test using repeated measures. Fisher test was used as post hoc test to determine significant difference among medias identified by ANOVA. Naka-Rushton equation parameters (b wave amplitude versus intensity of luminous stimulus) were initially evaluated by ANOVA variance analysis test of one and two factors, with adequate Bonferroni correction to the number of comparisons between groups and intervals. Differences were considered significant when $p$ was lower than 0.05 .

\section{RESULTS}

\section{Clinical Aspects}

No alterations were observed at biomicroscopy and indirect binocular ophthalmoscopy during the follow-up period (cataract, cells at anterior and posterior cameras, retinal lesion and endophthalmitis).

\section{Electroretinography}

Figure 1 shows scotopic and photopic ERG 
registers of one animal before and after ( 7 and 30 days) intravitreal injection of PS80 in the right eye and sterile saline in left eye. Visual inspection of ERG waves don't suggest secondary alteration of PS80 in the comparison of the day of intravitreal injection and after seven and 30 days.

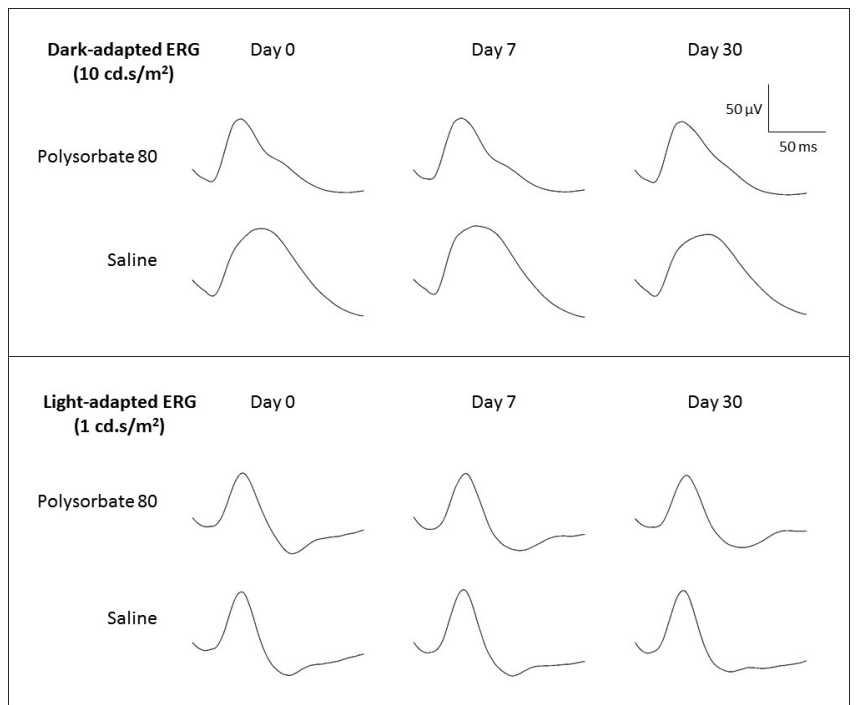

Figure 1. Representative electroretinograhy results.

To evaluate the dynamic interval of ERG at scotopic condition, graphics of median amplitude versus intensity of luminous stimulus were performed. Figure 2 shows that intravitreal injection of PS80 did not alter the dynamic interval of ERG compared to sterile saline injection. Obtained curve parameters $\left(V_{\text {max }} k\right.$ and $n)$ did not vary during time when the results of seven and 30 days were compared $(p>0,05)$.

Functional effects on retina of intravitreal injection of PS80 were also analyzed by the $V_{\max }$ relation (experimental eye/control eye) of b wave at scotopic state and of $b$ wave amplitude relation (experimental eye/control eye) at photopic condition. Register analysis don't show any alteration of the function of cones and rods ( $p>0.05$ ). Figure 3 shows these results.

ERG scotopic and photopic registers were not affected by intravitreal injection of PS80 at days zero, seven and 30 , as observed in figure 4 , that shows the relation between wave $b$ scotopic retinal function [ratio $V_{\max }$ (experimental eye/control eye) at scotopic state] and photopic [ratio wave b amplitude (experimental eye/control eye) at photopic condition].
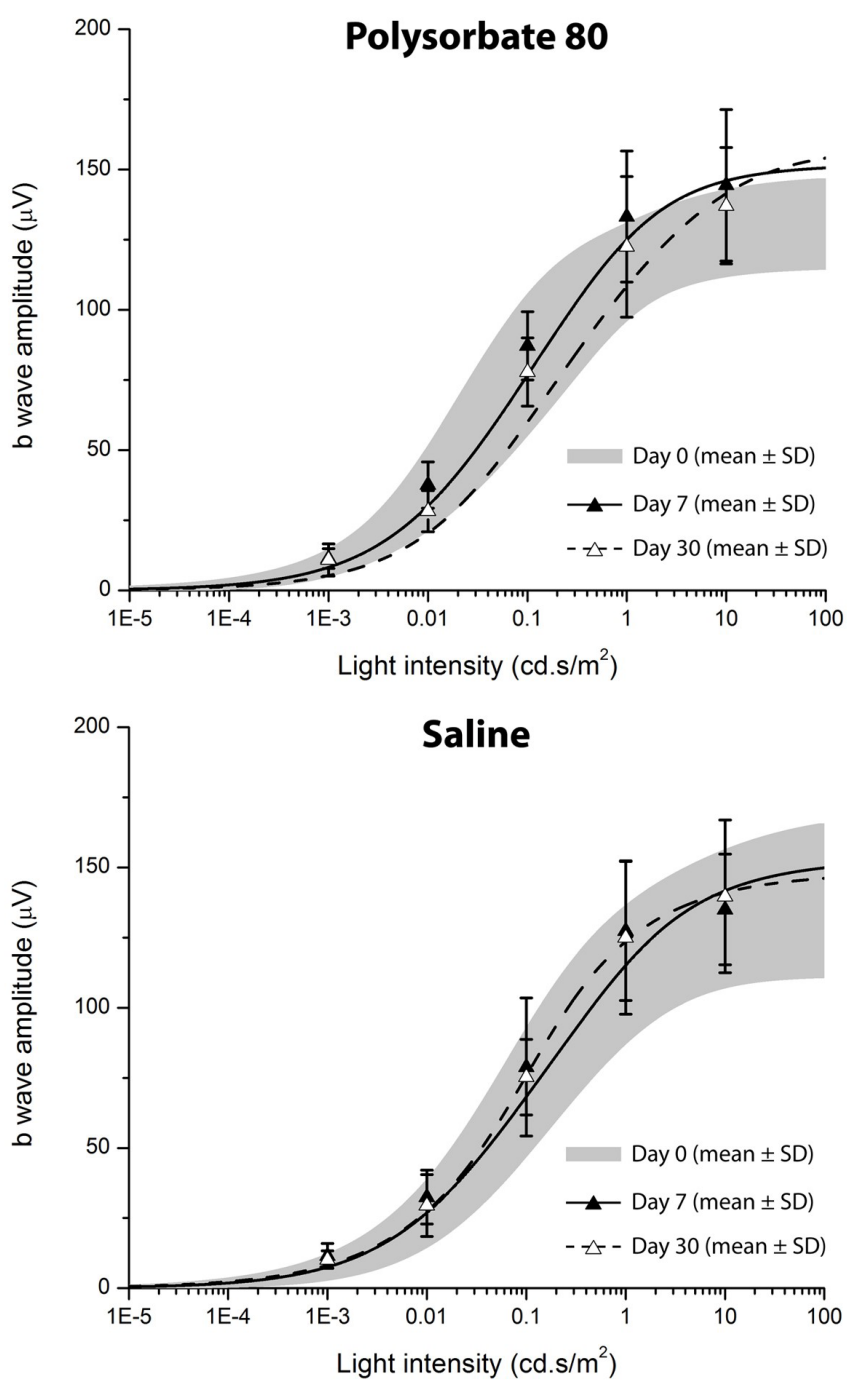

Figure 2. Scotopic b wave amplitude x luminous stimulus.

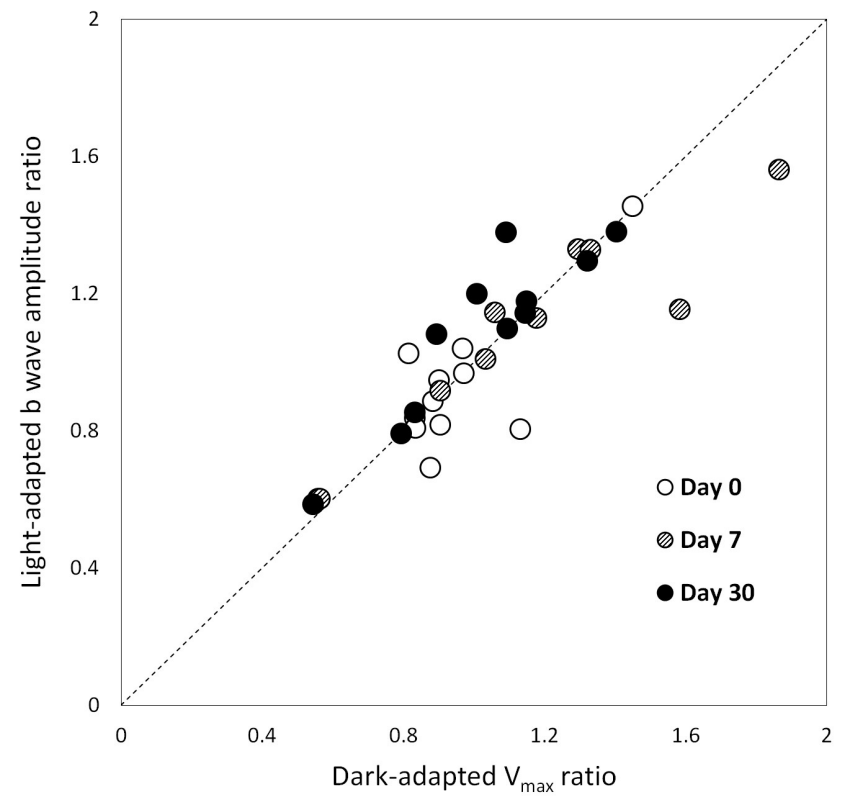

Figure 3. Ratio of scotopic $V_{\max } \times$ photopic $b$ wave amplitude. 
Intravitreal injection effects of PS80 in the relationship between a and b waves were also analyzed by amplitude graphics of $b$ wave in relation to a wave amplitude in all luminous intensities that generated detectable and measurable a waves $(0.1,1$ and $10 \mathrm{~cd} . \mathrm{s} /$ $\mathrm{m}^{2}$ at scotopic condition and $1 \mathrm{~cd} . \mathrm{s} / \mathrm{m}^{2}$ at photopic condition). Figure 5 demonstrates that PS80 intravitreal injection did not cause functional significant alterations when compared to sterile saline injection at the 7 th and 30th days after intravitreal injections in both tested conditions (scotopic and photopic).

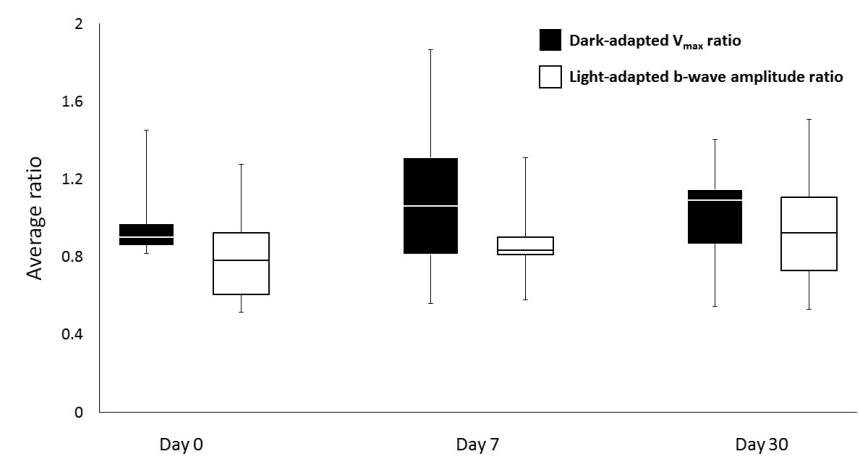

Figure 4. Scotopic and photopic retinal function.

\section{Histology}

Figure 6 shows representative histology images of right eye (PS80) and left eye (sterile saline) of the same animal. Thirty days after PS80 intravitreal injection, eyes did not present any histologic alteration under light microscopy compared to eyes that received intravitreal injection of sterile salinel.

\section{DISCUSSION}

In this experimental study, retinal functional and morphological effects of intravitreal injection of PS80 in rabbits were analyzed. Obtained results suggest that PS80 concentration used in this study (the same used in preparation of drugs for intravitreal use to treat retina diseases $(0.4 \% \mathrm{w} / \mathrm{v})$ is not toxic to rabbit retinas.

PS80 is a widely used component in the preparation of foods, vitamins, drugs and vaccines. PS80 stabilize aqueous formulas of drugs used intravenously; it is an emulsifier present in several drugs

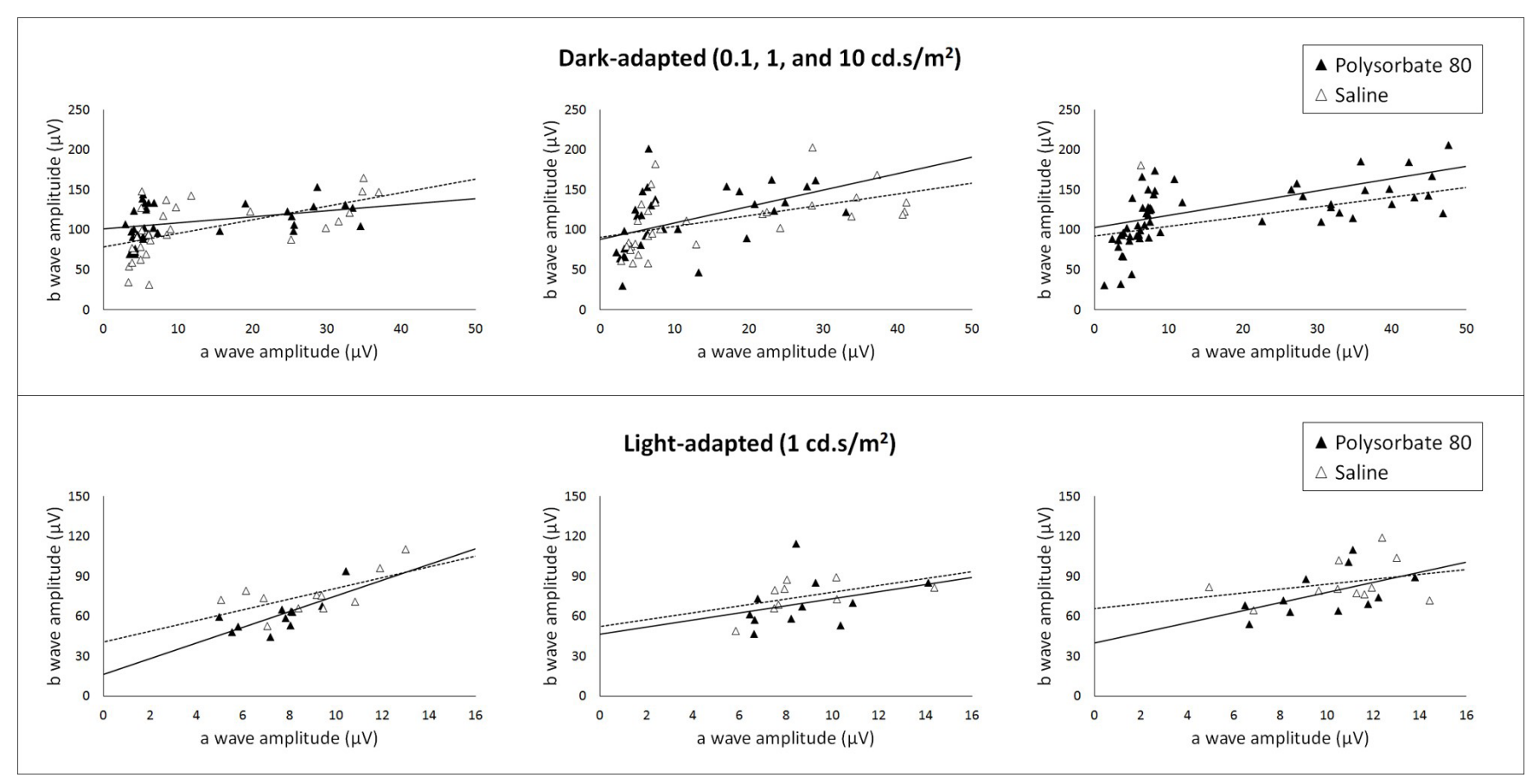

Figure 5. B wave amplitude $x$ stocopic and photopic a wave. 


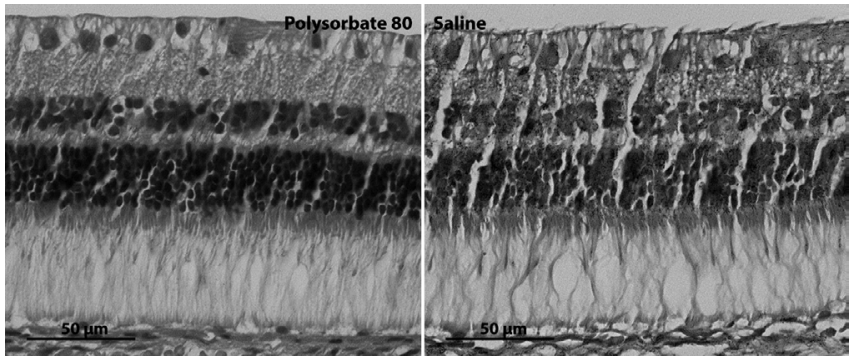

Figura 6. Histologia retiniana antes e 30 dias após PS80.

(amiodarone, ciclosporin and decetaxel) ${ }^{20}$ and it is used as excipient in vaccines ${ }^{21}$. Although PS80 is usually considered a safe component for systemic use and of several drugs for intravitreal use that include it in their formula, clinical and experimental studies of its safety are controversial, regarding intravitreal injections $5^{9,13-15,22}$. Since formula of drugs injected at vitreous contain many other agents (preservatives, surfactants, solvent and agents that stabilize $\mathrm{pH}$ and tonicity), the role of each agent regarding retinal toxicity is still uncertain ${ }^{16-18,23}$. One of the agents present in TA preparation injected in vitreous is benzylic alcohol, that has preservative and antibacterial proprieties. It has already been shown that benzylic alcohol causes early non-immunologic contact reaction in humans. Also, experimental data on teratogenesis and toxicity to reproductive processes are still controversial ${ }^{24}$. Maia et al. ${ }^{15}$ evaluated clinical and morphological alterations of rabbits retina secondary to sub-retinal injection of supernatants of TA solutions containing benzylic alcohol or not. Both tested solutions contained PS80 in their formula. Authors showed that eyes injected with TA supernatant that did not contain benzylic alcohol had lower grade of retinal lesion, suggesting that the presence of benzylic alcohol may, at least in part, be related to retinal toxicity.

Biochemical parameters also have a very important role in drug retinal toxicity. Osmolarity and $\mathrm{pH}$ may be responsible for alterations detected at ERG, indirect binocular ophthalmoscopy, angiography with fluorescein and histology ${ }^{25-28}$. Eyes that received intravitreal injections of compounds with non-physiologic pH and osmolarity may present retinal detachment ${ }^{27}$, alterations of $a$ and $b$ waves at ERG (lowering of amplitude and increase of implicit time $)^{25-27}$ and extra- and intracellular edema ${ }^{25}$. PS80 used in this study is the commercially available formula that is universally used in the preparation of drugs for intravitreal use (Tween $® 80$ ). Tween ${ }^{\circledR} 80$ has a pH very close to normal (6.6-6.8), and is iso-osmolar (288 a $318 \mathrm{mOsm} / \mathrm{kg} \mathrm{H}_{2} \mathrm{O}$ ). Therefore, it is very unlikely that biochemical factors associated to PS80 used in this study (such as $\mathrm{pH}$ and osmolarity) may cause retinal toxicity.

Since this is the first publication about the retinal effects of intravitreal injection of PS80, it is not possible to compare it directly with other results. However, PS80 is present is several drugs that are injected in vitreous of animals and studies don't show any retinal toxicity, such as Triesence $₫$ (a new TA formulation without preservative, specifically produced for intravitreal injection), Remicade $\left.{ }^{(i n f l i x i m a b e}\right)^{29-31}$ and Humira ${ }^{\circledR}$ (adalimumabe) ${ }^{32-34}$. These last two are monoclonal antibodies that block tumor necrosis factor approved for the treatment of gastrointestinal, rheumatic and dermatologic diseases, that have been used for the treatment of auto-immune uveitis.

This study has some limitations. Only one concentration of PS80 was tested. It did not allow us to determine the maximal safe dose for intravitreal injection, but the concentration tested is used in all formulations of drugs for intravitreal use. Also, no immune-histochemical analysis or ultramicroscopic studies were performed to detect subtle or subclinical alterations of retinal toxicity. This is an experimental study and the results may not represent integrally the findings of human inflamed eyes. Limitations of the use of rabbit eyes in the studies of drug retinal toxicity include retinal vascularization differences in relation to human eye, and differences of the eye volume of rabbits and humans. In spite of the cited limitations, this study results have low variability, in special of ERG results, even considering that exists several variability factors that are very difficult to control in studies with ERG in animals, that could influence the results ${ }^{35}$.

This study suggests that PS80, at the used concentration in the preparation of drugs for intravitreal use, is not toxic to rabbits retina and may be used safely as a component of the preparation of suspension of lipophilic drugs. However, pharmacological and additional retinal toxicity studies are needed to determine the safety of PS80 in multiple intravitreal injections in the same eye, since this is a very common treatment in daily practice. 


\title{
R E S U M O
}

\begin{abstract}
Objetivo: determinar os efeitos funcionais e morfológicos na retina de coelhos da concentração de PS80 utilizada na preparação de drogas intravítreas. Métodos: onze coelhos New Zealand receberam injeção intravítrea de $0,1 \mathrm{ml}$ de PS80. Como controle, o olho contralateral de cada coelho recebeu o mesmo volume de soro fisiológico. Foram realizados eletrorretinogramas de acordo com o protocolo modificado, biomicroscopia e mapeamento de retina antes da injeção, sete e dez dias depois. Os animais foram sacrificados no 30 o dia e as retinas analisadas por microscopia de luz. Resultados: os olhos injetados com PS80 não apresentaram sinais clínicos de inflamação intraocular. O eletrorretinograma não apresentou alteração de amplitude e tempo implícito das ondas a e b nas condições escotópica e fotópica. Não houve alteração morfológica da retina na microscopia de luz. Conclusão: a injeção intravítrea de PS80 na concentração utilizada na preparação de drogas intravítreas não causa alterações funcionais e morfológicas na retina de coelhos. Esses resultados sugerem que o PS80 não é tóxico para a retina de coelhos e pode ser usado com segurança na preparação de novas drogas lipofílicas para injeção intravítrea.
\end{abstract}

Descritores: Polissorbatos. Retina. Eletrorretinografia. Injeções Intravítreas. Achados Morfológicos e Microscópicos.

\section{REFERENCES}

1. Rodrigues EB, Maia M, Penha FM, Dib E, Bordon AF, Magalhães Júnior $\mathrm{O}$, et al. [Technique of intravitreal drug injection for therapy of vitreoretinal diseases]. Arq Bras Oftalmol. 2008;71(6):902-7. Portuguese.

2. Fialho SL, Cunha Júnior Ada S. [Drug delivery systems for the posterior segment of the eye: fundamental basis and applications]. Arq Bras Oftalmol. 2007;70(1):173-9. Portuguese.

3. Ema M, Hara $H$, Matsumoto $M$, Hirata-Koizumi $M$, Hirose A, Kamata E. Evaluation of developmental neurotoxicity of polysorbate 80 in rats. Reprod Toxicol. 2008;25(1):89-99.

4. Thackaberry EA, Kopytek S, Sherratt P, Trouba K, Mclntyre B. Comprehensive investigation of hydroxypropyl methylcellulose, propylene glycol, polysorbate 80, and hydroxypropyl-betacyclodextrin for use in general toxicology studies. Toxicol Sci. 2010;117(2):485-92.

5. Gajdová M, Jakubovsky J, Války J. Delayed effects of neonatal exposure to Tween 80 on female reproductive organs in rats. Food Chem Toxicol. 1993;31(3):183-90.

6. Coors EA, Seybold H, Merk HF, Mahler V. Polysorbate 80 in medical products and nonimmunologic anaphylactoid reactions. Ann Allergy Asthma Immunol. 2005;95(6):593-9.

7. Younis HS, Shawer M, Palacio K, Gukasyan HJ, Stevens GJ, Evering W. An assessment of the ocular safety of inactive excipients following sub- tenon injection in rabbits. J Ocul Pharmacol Ther. 2008;24(2):206-16.

8. Onizuka $N$, Uematsu $M$, Kusano $M$, Sasaki $H$, Suzuma K, Kitaoka $\mathrm{T}$. Influence of different additives and their concentrations on corneal toxicity and antimicrobial effect of benzalkonium chloride. Cornea. 2014;33(5):521-6.

9. Ayaki M, Yaguchi S, Iwasawa A, Koide R. Cytotoxicity of ophthalmic solutions with and without preservatives to human corneal endothelial cells, epithelial cells and conjunctival epithelial cells. Clin Exp Ophthalmol. 2008;36(6):553-9.

10. Ruiz-Moreno JM, Montero JA, Bayon A, Rueda J, Vidal M. Retinal toxicity of intravitreal triamcinolone acetonide at high doses in the rabbit. Exp Eye Res. 2007;84(2):342-8.

11. Oliveira RC, Messias A, Siqueira RC, BoniniFilho MA, Haddad A, Damico FM, et al. Vitreous pharmacokinetics and retinal safety of intravitreal preserved versus non-preserved triamcinolone acetonide in rabbit eyes. Curr Eye Res. 2012;37(1):55-61.

12. Ye YF, Gao YF, Xie HT, Wang HJ. Pharmacokinetics and retinal toxicity of various doses of intravitreal triamcinolone acetonide in rabbits. Mol Vis. 2014;20:629-36.

13. Kai W, Yanrong J, Xiaoxin L. Vehicle of triamcinolone acetonide is associated with retinal toxicity and transient increase of lens density. Graefe's Arch Clin Exp Ophthalmol. 2006;244(9):1152-9.

14. Kozak I, Cheng L, Mendez T, Davidson MC, 
Freeman WR. Evaluation of the toxicity of subretinal triamcinolone acetonide in the rabbit. Retina. 2006;26(7):811-7.

15. Maia M, Penha FM, Farah ME, Dib E, Príncipe A, Lima Filho $A A$, et al. Subretinal injection of preservativefree triamcinolone acetonide and supernatant vehicle in rabbits: an electron microscopy study. Graefes Arch Clin Exp Ophthalmol. 2008;246(3):379-88.

16. Morrison VL, Koh HJ, Cheng L, Bessho K, Davidson $M C$, Freeman WR. Intravitreal toxicity of the kenalog vehicle (benzyl alcohol) in rabbits. Retina. 2006;26(3):339-44.

17. Chang YS, Wu CL, Tseng SH, Kuo PY, Tseng SY. In vitro benzyl alcohol cytotoxicity: implications for intravitreal use of triamcinolone acetonide. Exp Eye Res. 2008;86(6):942-50.

18. Li Q, Wang J, Yang L, Mo B, Zeng H, Wang N, Liu W. A moephologic study of retinal toxicity induced by triamcinolone acetonide vehicles in rabbit eyes. Retina. 2008;28(3):504-10.

19. Marmor MF, Fulton AB, Holder GE, Miyake $Y$, Brigell $M$, Bach $M$; International Society for Clinical Electrophysiology of Vision. ISCEV Standard for fullfield clinical electroretinography (2008 update). Doc Ophthalmol. 2009;118(1):69-77.

20. Strickley RG. Solubilizing excipients in oral and injectable formulations. Pharm Res. 2004;21(2):20130.

21. Fox $C B$, Haensler J. An update on safety and immunogenicity of vaccines containing emulsion-based adjuvants. Expert Rev Vaccines. 2013;12(7):747-58.

22. Zhengyu S, Fang W, Ying F. Vehicle used for triamcinolone acetonide is toxic to ocular tissues of the pigmented rabbit. Curr Eye Res. 2009;34(9):76976.

23. Patel S, Barnett JM, Kim SJ. Retinal toxicity of intravitreal polyethylene glycol 400. J Ocul Pharmacol Ther. 2016;32(2):97-101.

24. Nair B. Final report on the safety assessment of Benzyl Alcohol, Benzoic Acid, and Sodium Benzoate. Int J Toxicol. 2001;20 Suppl 3:23-50.

25. Maia M, Margalit E, Lakhanpal R, Tso MO, Grebe $\mathrm{R}$, Torres $\mathrm{G}$, et al. Effects of intravitreal indocyanine green injection in rabbits. Retina. 2004;24(1):69-
79.

26. Liang C, Peyman GA, Sun G. Toxicity of intraocular lidocaine and bupivacaine. Am J Ophthalmol. 1998;125(2):191-6.

27. Marmor MF. Retinal detachment from hyperosmotic intravitreal injection. Invest Ophthalmol Vis Sci. 1979;18(12):1237-44.

28. Verstraeten TC, Chapman C, Hartzer M, Winkler BS, Trese MT, Williams GA. Pharmacologic induction of posterior vitreous detachment in the rabbit. Arch Ophthalmol. 1993;111(6):849-54.

29. Giansanti F, Ramazzotti M, Vannozzi L, Rapizzi E, Fiore $T$, laccheri $B$, et al. A pilot study on ocular safety of intravitreal infliximab in a rabbit model. Invest Ophthalmol Vis Sci. 2008;49(3):1151-6.

30. Theodossiadis PG, Liarakos VS, Sfikakis PP, Charonis A, Agrogiannis G, Kavantzas N, et al. Intravitreal administration of the anti-TNF monoclonal antibody infliximab in the rabbit. Graefes Arch Clin Exp Ophthalmol. 2009;247(2):273-81.

31. Giansanti F, Papucci L, Capaccioli S, Bacherini D, Vannozzi L, Witort E, et al. Ocular safety of infliximab in rabbit and cell culture models. J Ocul Pharmacol Ther. 2010;26(1):65-71.

32. Manzano RP, Peyman GA, Carvounis PE, Kivilcim $M$, Khan P, Chevez-Barrios $P$, et al. Ocular toxicity of intravitreous adalimumab (Humira) in the rabbit. Graefe's Arch Clin Exp Ophthalmol. 2008;246(6):907-11.

33. Manzano RP, Peyman GA, Carvounis PE, Damico FM, Aguiar RG, loshimoto GL, et al. Toxicity of highdose intravitreal adalimumab (Humira) in the rabbit. J Ocul Pharmacol Ther. 2011;27(4):327-31.

34. Myers AC, Ghosh F, Andréasson S, Ponjavic V. Retinal function and morphology in the rabbit eye after intravitreal injection of the TNF alpha inhibitor adalimumab. Curr Eye Res. 2014;39(11):1106-16.

35. Perlman I. Testing retinal toxicity of drugs in animal models using electrophysiological and morphological techniques. Doc Ophthalmol. 2009;118(1):3-28.

Received in: 30/07/2017

Accepted for publication: 23/08/2017

Conflict of interest: none. 
Source of funding: FAPESP 2007/02696-1 FAPESP

2007/56624-1

FAPESP $2014 / 26818-2$ $150614 / 2009-8$

\section{Mailing address:}

Francisco Max Damico

E-mail: fmdamico@usp.br/fmdamico@yahoo.com 